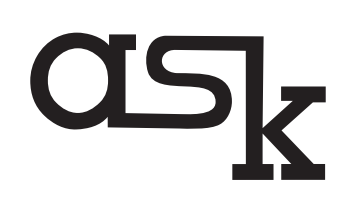

Research \& Methods ISSN 1234-9224, e-ISSN 2544-0799 Vol. 27 (1, 2018): 87-104 The Ohio State University Libraries Columbus, Ohio, USA Institute of Philosophy and Sociology

\title{
Europe of Uneven Data: Country Representation in International Surveys on Corruption, 1989-2017
}

\section{Ilona Wysmułek}

Institute of Philosophy and Sociology, Polish Academy of Sciences, Warsaw

\begin{abstract}
The fundamental principle of meaningful comparative analysis of corruption featuring crossnational survey data is that countries are equally represented across time. Yet, since 1989, this principle has been consistently violated. This article examines (a) the extent to which country coverage is uneven in 45 European countries in cross-national survey projects with items on corruption during 1989-2017 and (b) the dynamics of the change of inequalities in country representation. I examined a total of 89 survey waves of 21 international survey projects, including the Eurobarometer, the European Social Survey, the International Social Survey Program, the World Values Survey, and others. The results show that the differences in representation between European countries are systematic, significant, and rising. The Post-Soviet country group is particularly underrepresented both in specialized surveys on corruption and in general surveys with corruption items.
\end{abstract}

Keywords: Cross-national research, corruption, survey methodology, country representation, Europe

\section{INTRODUCTION}

The cross-national variation of corruption, defined as the misuse of entrusted power for private gains, has attracted great interest in the academic community and the media. The differences between countries with regard to the scale of both petty, street-level and grand, political corruption are remarkable (Nieuwbeerta, DeGeest and Siegers 2003, Rothstein 2011, Rose and Peiffer 2012, Heath et al. 2016). These real and (mis-)perceived cross-national differences in the scale of corruption have an impact on anti-corruption policies (Malito 2014, Mungiu-Pippidi 2017), 
investments decisions (Wei 2000), and individual problem-solving strategies ${ }^{1}$ (Melgar, Rossi and Smith 2010, Della Porta and Vannucci 2012), to name a few.

Our knowledge about cross-national differences in corruption often rely on public opinion surveys that measure both perceived and experienced corruption (Heath et al. 2016, Karalashvili, Kraay and Murrell 2015). These measures of corruption have proved to be informative and continue to drive analyses of causes and consequences of corruption (Povitkina and Wysmułek 2017).

Comparative researchers continue to face the challenge of unequal country representation in international survey projects, and undoubtedly the underrepresentation of countries in survey projects limits our knowledge about them. Previous studies of country representation reveal the uneven participation of East European countries in cross-national public opinion survey projects (Słomczyński and Tomescu 2006). We also have the evidence of inequalities in representation of Southeast European countries (Kolczynska 2014). However, the question of the nature of changes in countries' representation patterns in time and the scale of these patterns for corruption research is still open.

This article examines country representation in comparative research on corruption across Europe to determine the patterns of participation of 45 European countries in the cross-national public opinion surveys with items on corruption during the last three decades, 1989-2017. To do so, I created a dataset with a list of country-survey-years (1587 units of analysis) stemming from a comprehensive review of the largest collection of extant cross-national surveys suitable for research on corruption in Europe (Wysmułek 2017). Data on country participations was obtained from Eurobarometer, the Life in Transition Survey, the Global Corruption Barometer, the Crime Victims Survey, the European Social Survey, the International Social Survey Program, the World Values Survey, and others - a total of 89 survey waves of 21 international survey projects which include items on corruption in their questionnaires and have national samples that are intended to be representative of the adult population (see Table 1$)^{2}$. The analysis is motivated by the question whether there are countries or country regions that are underrepresented in the public opinion surveys with questions on corruption and whether inequalities in representation of countries change over time.

\section{Drivers of Comparative Research on Corruption}

Numerous reports prepared by international organizations reveal the remarkable variation in corruption between countries. There are countries where corrupt negotiations with public officials have been, and still are, the necessary condition for obtaining public services. At the same time in some countries corruption is a rare event and most citizens never experience it (Rothstein 2011, Heath et al. 
2016, Mungiu-Pippidi 2017). As Rose and Peiffer (2012) reflect: "In theory, all countries could be high in integrity. In practice, the distribution [of the Corruption Perception Index 2011] is skewed toward the bottom end of the corruption scale." (p.17). At the national level the consequences of corruption are also unevenly distributed. Just as the impact of the mechanism of corruption as a 'regressive tax' varies with the individual, on the national level the same degree of corruption can affect countries differently. As Kamiński (1997) puts it: "Rich nations can afford a pinch of decadence; this may be charming at times. For poor nations decadence is ominous" (p.91).

This seemingly national problem has a great impact on international trade and investment, which was probably one of the main stimuli to gather data on crossnational differences in corruption. Since mid-1990, together with profound economic and political changes in the global arena, the low corruption environment has been recognized by international organizations as one of the key elements of economic development in the contemporary global economy (Kamiński and Kamiński 2004).

An early advocate of an international battle against national corruption levels was the Organization for Economic Cooperation and Development (OECD), followed later also the United Nations, the World Bank, the European Union and the regional development banks. Yet, the key organization in popularizing the issue of cross-national differences in corruption has been Transparency International (TI) - ever since 1995, when the TI's yearly Corruption Perception Index was first launched, it has been fuelling the media debate on national corruption levels from a comparative perspective (Andersson and Heywood 2009). TI later introduced the Global Corruption Barometer survey project based on an adult population sample, which continues to play a leading role in providing survey data for corruption analysis, together with the World Bank Enterprise Survey based on a firm-level sample (Holmes 2015, Malito 2014, Chabova 2017). Since early 2000, corruption items have started to appear in non-specialized international surveys that cover the topic of corruption, along with other items on perceptions of government, democratic values, and institutional experiences.

In the last two decades we observe a rapid growth in the amount of comparative research on corruption. The researchers speak of Eastern-Central Europe vs the West, and of developed $v s$ developing countries; the countries are often treated as the context for opinions and behaviors framed in hierarchical models. The fundamental principle of meaningful comparative analysis on corruption that relies on crossnational survey data is that countries are not systematically misrepresented.

There are several methodological challenges facing the study of corruption with cross-national survey data. Corruption, given its secretive nature, is hard to capture in the interview situation. Some respondents are reluctant to answer sensitive questions, and some may understand the concept differently than intended 
by researchers (Azfar and Murrell 2009, Bertrand and Mullainathan 2001). The estimation of rare event determinants also remains problematic, given that reported corruption instances are, for most modern democracies, highly infrequent (Heath et al. 2016). Measuring the reliability, validity and comparability of corruption items, as well as assessing the quality of corruption measures - and broader surveys, remain a challenge (Malito 2014, Chabova 2017).

Słomczyński and Tomescu (2006) distinguish two main methodological problems for comparative research with uneven country coverage: first, the extent to which results for regions can be generalized; and second, the risk of distorted distributions for models that treat countries as a macro-level context. Identification of the country representation in cross-national survey projects on corruption is one of the most significant sources of bias for comparative research, but it is rarely addressed explicitly.

\section{In Search for Survey Data on Corruption: Data Availability and Use}

The growing availability of survey data on corruption offers rich topic coverage and multiple research opportunities, but also demands knowledge about where the data sources are located, and what issues and countries they cover. Although there are new research tools available at data archives that aid location of data on a given subject, yet still many of the sources are placed on individual project web-sites that are not covered by these search tools (Smith 2015, Wysmulek 2016). Moreover, corruption data appears in surveys that are corruption-themed, but also in highquality general surveys that are not specialized in corruption, and while there is an awareness among corruption researchers about the former, the later sources are often overlooked. Corruption data from the high-quality non-specialized surveys is often freely available, but it is dispersed and thus demands additional effort if it is to be found. To examine country coverage in cross-national survey projects, it seems necessary to look at both corruption-themed survey projects and nonspecialized international survey projects with items on corruption.

The data and documentation of the survey projects suitable for comparative corruption research can be found on project websites or in the survey data archives. There are three main data archives with collections of cross-national survey data that cover, among others, the subject of corruption:

- the GESIS Data Archive for the Social Sciences (https://dbk.gesis.org/ dbksearch),

- the UK Data Service (http://discover.ukdataservice.ac.uk), and

- the ICPSR Inter-university Consortium for Political and Social Research (www.icpsr.umich.edu).

One third of all cross-national surveys discussed in this paper and relevant for research on corruption are located on separate project web-sites (see Appendix A1). 
These are: The Caucasus Barometer, The Global Corruption Barometer, the European Social Survey, the European Quality of Government Survey, the International Crime Victim Survey, the Life in Transition Survey and the Pew Global Attitudes Project.

To find existing survey data on corruption, the metadata created within the Data Harmonization Project (also called Survey Data Recycling project, SDR, www.dataharmonization.org) proved to be a useful source of information for this study. Although this is not an archiving institution, it provides the comprehensive metadata on the availability of items in cross-national survey projects since 1964 and offers indicators of the quality of these data (Słomczyński et al. 2016, Słomczyński et al. 2017) ${ }^{3}$.

\section{DATA AND METHODOLOGY}

To examine the coverage of European countries in international survey projects suitable for corruption research, I rely on three types of instruments: (1) Specialized cross-national surveys on corruption, (2) General intercontinental and European surveys with items on corruption and (3) Regional surveys with items on corruption. The first type is driven by the content criterion: it highlights the surveys that include batteries of questions on corruption - these surveys are most widely used in comparative corruption research. The remaining two types of instruments are non-specialized surveys on corruption, categorized by their intentions of area coverage. Regional surveys are included in this study with the intent of exploring possibilities for combining different data sources to overcome inequalities in country representation.

I analyze the representation of 45 European countries in a total of 21 survey projects and the 89 waves from 1989 to 2017. I pulled the data and documentation from these sources to create a merged dataset with variables on country name, survey project, edition/wave, year of the interview. The dataset includes in total 1587 country-survey-year units, forming the basis for analysis in this paper.

To capture the differences in patterns of participation, I conduct analysis on the level of countries and country regions in Europe. I have grouped countries into following categories:

A. Post-Soviet countries

A1. Belarus, Moldova, Russia, Ukraine

A2. Baltic States: Estonia, Latvia, Lithuania

A3. Caucasus: Armenia, Azerbaijan, Georgia

B. Post-Socialist countries

B1. The South-East: Albania, Bulgaria, Romania

B2. Former Yugoslavia: Bosnia-Herzegovina, Croatia, Kosovo, Macedonia, Montenegro, Serbia, Slovenia 
B3. Visegrad: the Czech Republic, Hungary, Poland, Slovakia C. Western countries

C1. Benelux: Belgium, Luxembourg, the Netherlands

C2. Western: Austria, France, German, Ireland, Switzerland, United Kingdom

C3. Southern: Andorra, Cyprus, Greece, Italy, Malta, Portugal, Spain

C4. Nordic: Denmark, Finland, Iceland, Norway, Sweden

The list of survey projects included in this study is informed by a systematic review of cross-national survey data in the search for items on corruption. The review resulted in the collection of 1129 corruption items dispersed in 21 survey projects in Europe since 1989 (see Appendix A2). The common characteristics of survey projects are that they: are cross-national; intend to have representative samples of the adult population of a country; are freely available through data archives or project web-sites and documented in English. This list does not include country specific surveys and surveys with a specific target sample, for example firm-level survey data gathered in the World Bank Enterprise Surveys project (details on methodology of the review presented in Wysmułek 2017).

The next section is divided into two parts: First, I present the analysis of participation rates for Post-Soviet, Post-Socialist and Western regions, and for ten subgroups of countries within these regions by survey type; and second, I examine the changes in patterns of European countries' representation from 1989 to 2017.

\section{RESULTS}

\subsection{Participation Patterns of European Countries across Public Opinion Surveys on Corruption}

The analysis of countries' participation in cross-national surveys on corruption confirms the existence of differences between participation patterns of Post-Soviet, Post-Socialist and Western countries within survey projects. To determine the scale of these differences by survey type, Table 1 presents the basic information on survey projects with items on corruption and gives the frequencies with which Post-Soviet, Post-Socialist and Western countries participated in those projects. The table contains information on the total sum of participation per region and the average participation of a country in a region. For example, the total frequency of participation of Post-Soviet countries in the International Crime Victims Survey is 20 times, and the average that each of ten countries in Post-Soviet group region participated in the survey is two out of four possible times (as ICVS has a total of four waves with items on corruption). The survey projects are sorted in Table 1 by survey types and then - by the scope of countries' coverage, based on the average number of Europe countries per wave for each survey project. 
Table 1. European Countries' Representation in Cross-National Surveys with Items on Corruption

\begin{tabular}{|c|c|c|c|c|c|}
\hline \multirow{2}{*}{ Survey name (abbreviation) } & \multirow{2}{*}{ Waves } & \multirow{2}{*}{$\begin{array}{l}\text { Europe } \\
\text { countries } \\
\text { (wave } \\
\text { average) }\end{array}$} & \multicolumn{3}{|c|}{$\begin{array}{c}\text { Total sum (country average) } \\
\text { of participation }\end{array}$} \\
\hline & & & $\begin{array}{l}\text { Post- } \\
\text { Soviet }\end{array}$ & $\begin{array}{l}\text { Post- } \\
\text { Socialist }\end{array}$ & Western \\
\hline
\end{tabular}

(a) Specialized surveys on corruption

Global Corruption Barometer (GCB)

Life in Transition Survey (LITS)

Eurobarometer Corruption Themed 64.3, 68.2, 72.2, 76.1, 79.1, 88.2 (EB_corr)

International Crime Victims Survey (ICVS)

$\begin{array}{rrrrr}8 & 31 & 47(4.7) & 77(5.5) & 122(5.8) \\ 3 & 27 & 30(3) & 41(2.9) & 9(0.4) \\ 6 & 23 & 15(1.5) & 37(2.6) & 86(4.1) \\ 4 & 22 & 20(2) & 25(1.8) & 44(2.1)\end{array}$

(b) General surveys with items on corruption

European Values Study (EVS)

European Quality of Life Survey (EQLS)

General Eurobarometer (EB)

European Social Survey (ESS)

Comparative Study of Electoral Systems (CSES)

European Quality of Government Survey (QoG)

International Social Survey Programme (ISSP)

World Values Survey (WVS)

Asia Europe Survey (ASES)

International Social Justice Project (ISJP)

Pew Global Attitudes Project (PEW)

$\begin{array}{rrrrr}3 & 34 & 19(1.9) & 29(2.1) & 53(2.5) \\ 1 & 32 & 3(0.3) & 12(0.9) & 17(0.8) \\ 13 & 27 & 33(0.3) & 83(5.9) & 232(11) \\ 2 & 24 & 5(0.5) & 12(0.9) & 31(1.5) \\ 1 & 23 & 1(0.1) & 7(0.5) & 15(0.7) \\ 2 & 21 & 1(0.1) & 15(1.1) & 26(1.2) \\ 9 & 17 & 19(1.9) & 44(3.1) & 91(4.3) \\ 5 & 16 & 24(2.4) & 30(2.1) & 27(1.3) \\ 1 & 9 & 0(0) & 0(0) & 9(0.4) \\ 2 & 9 & 4(0.4) & 9(0.6) & 5(0.2) \\ 6 & 8 & 9(0.9) & 17(1.2) & 19(0.9)\end{array}$

(c) Regional surveys with items on corruption

Consolidation of Democracy in Central and Eastern Europe (CDCEE)

Candidate Countries Eurobarometer (CCEB)

New Europe Barometer (NEB)

Values and Political Change in Postcommunist

Europe (VPCPCE)

Caucasus Barometer (CB)

New Baltic Barometer (NBB)

$\begin{array}{rrrrr}2 & 13 & 10(1.0) & 14(1.0) & 2(0.1) \\ 2 & 12 & 6(0.6) & 14(1.0) & 4(0.2) \\ 5 & 8 & 15(1.5) & 27(1.9) & 0(0) \\ 1 & 5 & 2(0.2) & 3(0.2) & 0(0) \\ 7 & 3 & 19(1.9) & 0(0) & 0(0) \\ 6 & 3 & 17(1.7) & 0(0) & 0(0) \\ 89 & & 299(30) & \mathbf{4 9 6 ( 3 5 )} & \mathbf{7 9 2 ( 3 8 )}\end{array}$

TOTAL

$299(30) \quad 496(35) \quad 792(38)$

The results show that in the two largest survey projects devoted to corruption - the Global Corruption Barometer and the Corruption Themed Eurobarometer the Post-Soviet countries of Europe are underrepresented as compared to the West (Table 1, survey type A). The differences are most pronounced in Eurobarometer, where on average Western countries are represented in $70 \%$ of data gathered 
on corruption, and Post-Soviet countries - in only $25 \%$, which also reflects the pattern of membership of Post-Soviet countries in the European Union. The Life in Transition survey fills this gap, collecting data on corruption mostly from PostSoviet and Post-Socialist countries. The most balanced participation pattern is offered by the oldest cross-national dataset on corruption, which is the International Crime Victims Survey - on average the participation of countries representing Post-Soviet, Post-Socialist and Western Europe is even across its waves.

The representation of Western countries also dominates in the vast majority of general cross-national surveys with some items on corruption (Table 1, survey type B). The uneven participation of European regions seems to persist in the survey projects with a long tradition and a number of waves, such as the European Values Study, the General Eurobarometer, the International Social Science Programme and the European Social Survey; the differences in country group participation are also visible within the newly launched projects, such as the European Quality of Government Survey. The representation of Post-Socialist countries within the general survey projects on corruption is on average better than that of Post-Soviet countries.

Regional surveys with items on corruption follow a different pattern (Table 1, survey type C). All regional surveys discussed concentrate almost exclusively on countries outside the West of Europe. On one hand, the regional data seems to fill the gap in corruption data suitable for comparable research. On the other hand, it indicates an interesting tendency to run separate surveys for certain regions, rather than participating in the large survey infrastructures. These peculiarities of regional participation patterns in survey projects have consequences for comparative corruption research.

To compare countries' participation patterns across survey projects, a weighted measure of participation for country groups in Europe was constructed by averaging the number of waves that a country from a given group participated in, and weighting this measure by the total number of waves of each project in which potentially a country could have participated. In other words, the weighted participation rate is calculated as the sum of all survey waves in which a country group participated divided by the respective number of countries in each category (region) and by the total number of survey waves with items on corruption in a project. Table 2 presents the results that are based on this measure to show the participation rates by European country groups and survey types. Please note that the total participation rates are not calculated for regional surveys, - although the weighted measure of participation rate is telling for regions within surveys, it is not comparable across surveys, as those surveys did not aim to include all European countries. 
Table 2. Weighted Participation Rate of European Countries in Surveys on Corruption, 1989-2017

\begin{tabular}{|c|c|c|c|c|c|c|c|c|c|c|c|}
\hline & \multirow{3}{*}{$\begin{array}{c}\text { Total } \\
\text { number } \\
\text { of waves }\end{array}$} & \multicolumn{2}{|c|}{ A. Post-Soviet } & \multicolumn{4}{|c|}{ B. Post-Socialist } & \multicolumn{4}{|c|}{ C. Western } \\
\hline & & \multicolumn{10}{|c|}{ Average number of waves a country in a subgroup participated } \\
\hline & & A1 & A2 & A3 & B1 & B2 & B3 & $\mathrm{C} 1$ & $\mathrm{C} 2$ & $\mathrm{C} 3$ & $\mathrm{C} 4$ \\
\hline $\begin{array}{l}\text { \# of countries in } \\
\text { a sub-group }\end{array}$ & & 4 & 3 & 3 & 3 & 7 & 4 & 3 & 6 & 7 & \\
\hline
\end{tabular}

(a) Specialized surveys on corruption

\begin{tabular}{|c|c|c|c|c|c|c|c|c|c|c|c|}
\hline GCB & 8 & 6,0 & 3,7 & 4,0 & 6,7 & 5,6 & 4,5 & 5,3 & 6,8 & 4,6 & 6,6 \\
\hline LITS & 3 & 3,0 & 3,0 & 3,0 & 3,0 & 2,9 & 3,0 & 0,0 & 0,7 & 0,6 & 0,2 \\
\hline EB_corr & 6 & 0,0 & 5,0 & 0,0 & 3,3 & 1,0 & 5,0 & 5,0 & 4,2 & 4,4 & 3,0 \\
\hline ICVS & 4 & 1,8 & 3,0 & 1,3 & 2,3 & 0,9 & 3,0 & 2,7 & 2,5 & 1,3 & 24 \\
\hline Total & 21 & 10,8 & 14,7 & 8,3 & 15,3 & 10,4 & 15,5 & 13,0 & 14,2 & 10,9 & 12,2 \\
\hline Participation rate & & 0,5 & 0,7 & 0,4 & 0,7 & 0,5 & 0,7 & 0,6 & 0,7 & 0,5 & \\
\hline \multicolumn{12}{|c|}{ (b) General surveys with items on corruption } \\
\hline EVS & 3 & 1,8 & 3,0 & 1,0 & 2,3 & 1,4 & 3,0 & 2,7 & 2,7 & 2,1 & \\
\hline EQLS & 1 & 0,0 & 1,0 & 0,0 & 1,0 & 0,7 & 1,0 & 1,0 & 0,8 & 0,9 & \\
\hline EB & 13 & 0,0 & 11,0 & 0,0 & 7,3 & 2,4 & 11,0 & 14,0 & 11,7 & 11,1 & 8,4 \\
\hline ESS & 2 & 0,8 & 0,7 & 0,0 & 0,3 & 0,4 & 2,0 & 1,7 & 1,7 & 1,1 & 1,6 \\
\hline CSES & 1 & 0,3 & 0,0 & 0,0 & 1,0 & 0,1 & 0,8 & 0,7 & 0,8 & 0,4 & \\
\hline QoG & 2 & 0,3 & 0,0 & 0,0 & 1,3 & 0,4 & 2,0 & 1,3 & 1,5 & 1,1 & \\
\hline ISSP & 9 & 2,0 & 3,0 & 0,7 & 1,3 & 1,7 & 7,0 & 2,0 & 6,2 & 2,6 & 0,0 \\
\hline WVS & 5 & 3,3 & 1,3 & 2,3 & 2,3 & 2,1 & 2,0 & 0,7 & 1,5 & 1,3 & \\
\hline ASES & 1 & 0,0 & 0,0 & 0,0 & 0,0 & 0,0 & 0,0 & 0,0 & 0,7 & 0,6 & \\
\hline ISJP & 2 & 0,5 & 0,7 & 0,0 & 0,7 & 0,1 & 1,5 & 0,7 & 0,5 & 0,0 & \\
\hline PEW & 6 & 2,0 & 0,3 & 0,0 & 1,0 & 0,0 & 3,5 & 0,0 & 1,7 & 1,1 & \\
\hline Total & 45 & 11 & 21 & 4 & 18,5 & 9,3 & 33,8 & 24,8 & 29,8 & 22,3 & \\
\hline Participation rate & & 0,2 & 0,5 & 0,1 & 0,4 & 0,2 & 0,8 & 0,6 & 0,7 & 0,5 & \\
\hline
\end{tabular}

(c) Regional surveys with items on corruption

\begin{tabular}{lrrrrrrrrrrr} 
CDCEE & 2 & 1,3 & 1,7 & 0,0 & 1,3 & 0,3 & 2,0 & 0,0 & 0,3 & 0,0 & 0,0 \\
CCEB & 2 & 0,0 & 2,0 & 0,0 & 1,3 & 0,3 & 2,0 & 0,0 & 0,0 & 0,6 & 0,0 \\
NEB & 5 & 2,3 & 2,0 & 0,0 & 2,0 & 1,3 & 3,0 & 0,0 & 0,0 & 0,0 & 0,0 \\
VPCPCE & 1 & 0,5 & 0,0 & 0,0 & 0,0 & 0,0 & 0,8 & 0,0 & 0,0 & 0,0 & 0,0 \\
CB & 7 & 0,0 & 0,0 & 6,3 & 0,0 & 0,0 & 0,0 & 0,0 & 0,0 & 0,0 & 0,0 \\
NBB & 6 & 0,0 & 5,7 & 0,0 & 0,0 & 0,0 & 0,0 & 0,0 & 0,0 & 0,0 & 0,0 \\
Total & $\mathbf{2 3}$ & $\mathbf{4 , 1}$ & $\mathbf{1 1 , 4}$ & $\mathbf{6 , 3}$ & $\mathbf{4 , 6}$ & $\mathbf{1 , 9}$ & $\mathbf{7 , 8}$ & $\mathbf{0}$ & $\mathbf{0 , 3}$ & $\mathbf{0 , 6}$ & $\mathbf{0}$ \\
Participation rate & & $\mathbf{0 , 2}$ & $\mathbf{0 , 5}$ & $\mathbf{0 , 3}$ & $\mathbf{0 , 2}$ & $\mathbf{0 , 1}$ & $\mathbf{0 , 3}$ & $\mathbf{0 , 0}$ & $\mathbf{0 , 0}$ & $\mathbf{0 , 0}$ & $\mathbf{0 , 0}$ \\
\hline
\end{tabular}


The results presented in Table 2 allow us to observe the variation of participation patterns in survey projects within the Post-Soviet, Post-Socialist and Western European regions. In the Post-Soviet region, the Caucasus countries (A3 group) have the lowest participation rate both in the specialized and general surveys with items on corruption - on average their participation rate is 0.4 and 0.1 , respectively, meaning that they participated only in $40 \%$ and $10 \%$ of all potential waves. The important representation of Armenia, Azerbaijan and Georgia occurs within the regional Caucasus Barometer that has been conducted regularly since 2009 and includes questions on corruption. Moldova and Belarus (A1 group) also deserve special attention, as they are covered in only 16 and 18 percent of all survey waves discussed in this paper (see Figure 1 for participation rates on the level of countries).

The Post-Socialist region is on average better represented in cross-national surveys than Post-Soviet countries. Compared to the West, the participation rate of the Post-Socialist countries is even slightly higher for specialized surveys, but on average lower for general surveys. Within the Post-Socialist region, Former Yugoslavia (B2 group) is a special case: it is on average underrepresented across all survey projects discussed in this paper. It is interesting that the variation of participation rate within the Former Yugoslavia group itself is high and ranges from 0.07 in Montenegro up to 0.56 in Slovenia.

Figure 1. Map of Europe Countries' Participation Rates in Cross-national Surveys on Corruption, 1989-2017

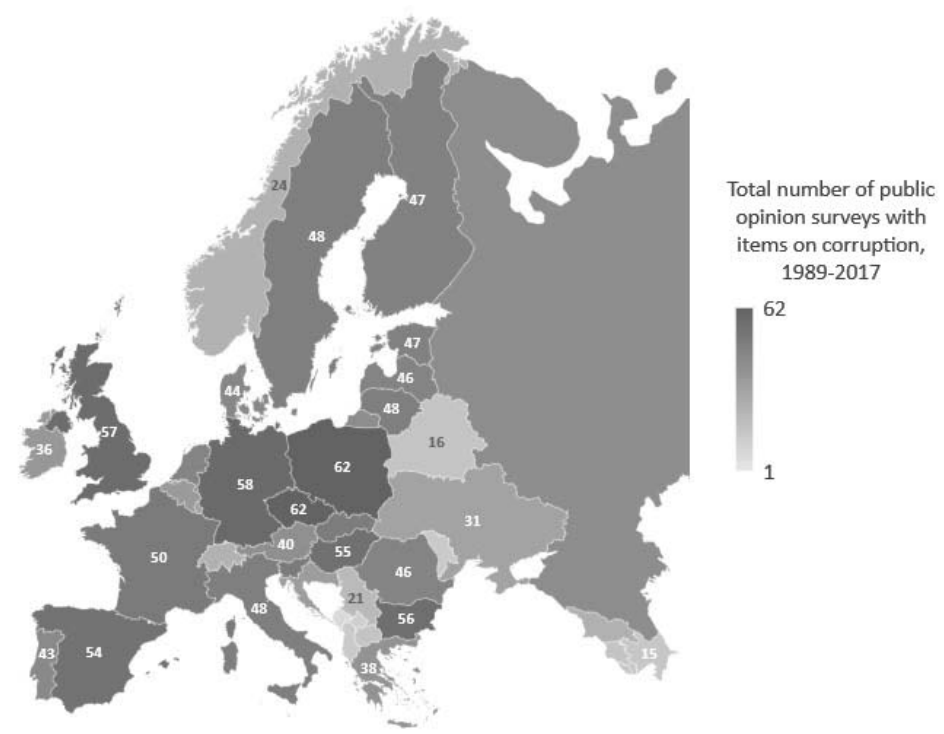


Within Western countries, the lowest participation rates and the greatest withingroup variation can be observed in the Western-Southern group C3. Since 1989, most survey waves with items on corruption have been launched in Spain, Portugal and Italy, some in Greece, Cyprus and Malta, and only one in Andorra.

\subsection{Changes in European Countries' Participation Patterns across Time}

With the growing amount of survey data in general, the question arises whether the participation patterns of different country groups change over time. Table 3 presents the total number of public opinion surveys on corruption by countries and country groups in five-year periods.

First and above all, Table 3 illustrates the increasing trend in the amount of data on corruption since 2001. Second, the Visegrad Four countries, which are the Czech Republic Hungary, Slovakia and, Poland, stand out as the ones having the longest traditions of participation in cross-national survey projects and collection of public opinion data on corruption. Their total number of surveys on corruption per country was already high in 1989-1994, as in Russia, Estonia, Bulgaria, Slovenia and Germany ${ }^{4}$. Third, Table 3 illustrates that some countries are consistently underrepresented - which is for example the case of countries of Former Yugoslavia (with the exception of Croatia). An interesting trend can be also observed in Norway, Iceland and Switzerland - after a peak in 2001-2005, the number of surveys in those countries has been rapidly declining.

Table 3. Dynamics of Country Participation in Public Opinion Surveys on Corruption by European Regions, 1989-2017

\begin{tabular}{|c|c|c|c|c|c|c|c|}
\hline & Country & $1989 / 1994$ & $1995 / 2000$ & $2001 / 2006$ & $2007 / 2011$ & $2012 / 2017$ & Total \\
\hline \multirow{10}{*}{ 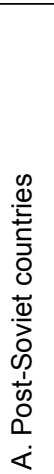 } & A1 Belarus & 2 & 6 & 2 & 5 & 1 & 16 \\
\hline & Moldova & 1 & 1 & 5 & 5 & 2 & 14 \\
\hline & Russia & 8 & 6 & 13 & 10 & 4 & 41 \\
\hline & Ukraine & 3 & 6 & 8 & 10 & 4 & 31 \\
\hline & A2 Estonia & 7 & 6 & 11 & 11 & 12 & 47 \\
\hline & Latvia & 3 & 8 & 12 & 10 & 13 & 46 \\
\hline & Lithuania & 4 & 7 & 11 & 12 & 14 & 48 \\
\hline & A3 Armenia & 1 & 0 & 1 & 8 & 6 & 16 \\
\hline & Azerbaijan & 1 & 1 & 1 & 8 & 4 & 15 \\
\hline & Georgia & 2 & 2 & 5 & 8 & 8 & 25 \\
\hline
\end{tabular}




\begin{tabular}{|c|c|c|c|c|c|c|c|}
\hline \multicolumn{2}{|r|}{ B1 Albania } & 1 & 3 & 4 & 3 & 3 & 14 \\
\hline \multirow{13}{*}{ 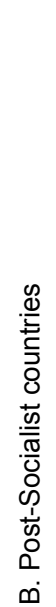 } & Bulgaria & 6 & 6 & 15 & 16 & 13 & 56 \\
\hline & Romania & 3 & 5 & 12 & 13 & 13 & 46 \\
\hline & B2 Bosnia and Herzeg. & 1 & 1 & 4 & 5 & 2 & 13 \\
\hline & Croatia & 1 & 4 & 9 & 7 & 13 & 34 \\
\hline & Kosovo & 0 & 0 & 3 & 5 & 3 & 11 \\
\hline & Macedonia & 1 & 2 & 5 & 5 & 3 & 16 \\
\hline & Montenegro & 1 & 1 & 1 & 2 & 2 & 7 \\
\hline & Serbia & 2 & 4 & 6 & 5 & 4 & 21 \\
\hline & Slovenia & 6 & 5 & 13 & 12 & 14 & 50 \\
\hline & B3 Czech Republic & 9 & 6 & 15 & 16 & 16 & 62 \\
\hline & Hungary & 7 & 6 & 12 & 14 & 16 & 55 \\
\hline & Poland & 6 & 6 & 18 & 17 & 15 & 62 \\
\hline & Slovakia & 7 & 5 & 9 & 13 & 15 & 49 \\
\hline & C1 Belgium & 2 & 3 & 7 & 10 & 13 & 35 \\
\hline & Luxembourg & 0 & 2 & 9 & 10 & 11 & 32 \\
\hline & Netherlands & 4 & 4 & 13 & 13 & 12 & 46 \\
\hline & C2 Austria & 2 & 4 & 10 & 12 & 12 & 40 \\
\hline & France & 1 & 6 & 14 & 14 & 15 & 50 \\
\hline & Germany & 6 & 5 & 15 & 16 & 16 & 58 \\
\hline & Ireland & 1 & 3 & 11 & 10 & 11 & 36 \\
\hline & Switzerland & 2 & 2 & 11 & 6 & 3 & 24 \\
\hline & United Kingdom & 5 & 7 & 15 & 15 & 15 & 57 \\
\hline & C3 Andorra & 0 & 0 & 1 & 0 & 0 & 1 \\
\hline & Cyprus Republic & 0 & 1 & 7 & 10 & 12 & 30 \\
\hline & Greece & 0 & 3 & 8 & 12 & 15 & 38 \\
\hline & Italy & 3 & 3 & 13 & 14 & 15 & 48 \\
\hline & Malta & 1 & 2 & 3 & 7 & 10 & 23 \\
\hline & Portugal & 1 & 5 & 12 & 13 & 12 & 43 \\
\hline $\mathscr{\mathscr { Q }}$ & Spain & 4 & 6 & 14 & 15 & 15 & 54 \\
\hline$\stackrel{\mathrm{t}}{5}$ & C4 Denmark & 1 & 3 & 13 & 13 & 14 & 44 \\
\hline 0 & Finland & 3 & 4 & 14 & 12 & 14 & 47 \\
\hline$\frac{1}{10}$ & Iceland & 1 & 1 & 5 & 5 & 2 & 14 \\
\hline$\stackrel{\infty}{3}$ & Norway & 3 & 1 & 11 & 6 & 3 & 24 \\
\hline$\dot{0}$ & Sweden & 4 & 6 & 11 & 14 & 13 & 48 \\
\hline
\end{tabular}


Figure 2 shows the changing pattern in average participation rates for a country within the Post-Soviet, Post-Socialist and Western country groups during the last three decades. In 1989-1999, most of the data on corruption came from the Post-Socialist and Post-Soviet block of countries. The pattern has changed since 2000-2009, when representation of Western countries in cross-national surveys started to dominate - which is also visible in existing data on corruption from the last decade. We can observe not only the shift in the pattern of representation of Western countries, but also the overall growing gap between participation rates in cross-national surveys on corruption for these three regions of Europe.

Figure 2. Changes in Weighted Participation Rate of Post-Soviet, Post-Socialist and Western European countries in 1989-2017

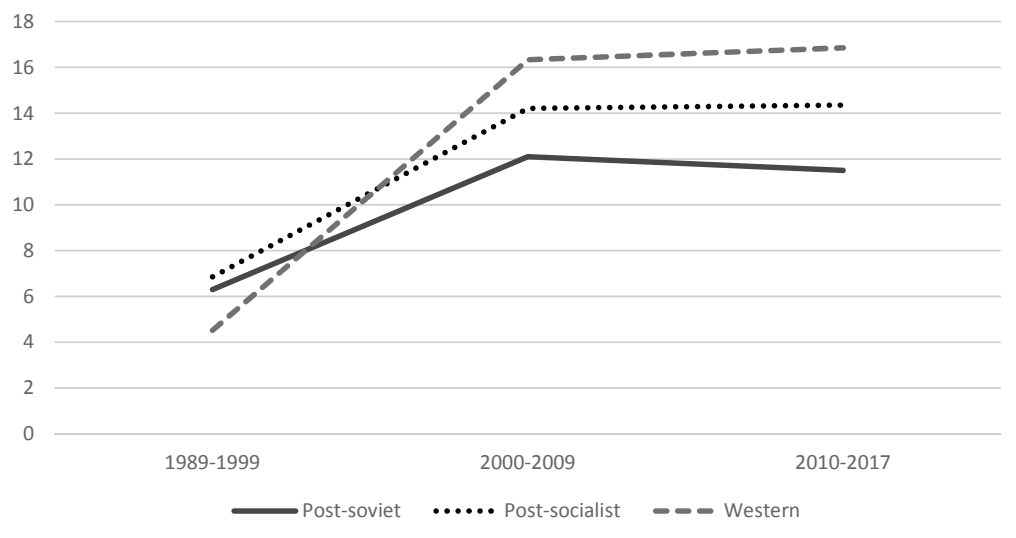

\section{SUMMARY AND DISCUSSION}

Uneven country representation may have a broad spectrum of consequences for corruption research. Recognizing its possible harmful effects for comparative analysis, this paper analyzed the patterns of participation of 45 European countries in cross-national survey projects with items on corruption in the period 19892017, to determine the extent to which country coverage is uneven in Europe, and to explore the dynamics of the change in inequalities of countries' representations. The findings demonstrate that the differences between participation patterns of European countries remain significant and increase with time, with the Post-Soviet country group being in general underrepresented both in specialized surveys on corruption and in general surveys with corruption items. 
The current inequalities in countries' participation rates in cross-national survey projects can be partially explained by differentiated historical paths, which had their impact on development of survey research infrastructure, and also on the social networks, interests and skills of individual researchers (Słomczyński and Tomescu 2006, Lynn, Japec and Lyberg 2006). Another important factor to explain the uneven participation of countries in large international projects is the difference in levels of economic development of countries in Europe. Conducting a survey is an expensive endeavor and the decision to participate in a project with high quality standards is also related to an assessment of economic resources (Groves 2004). Moreover, collecting data on corruption can be difficult (or welcomed) in some political contexts. The influence of political environments on corruption research is particularly visible in countries that underwent transformation (as in the 'corruption paradox' of post-communist countries, studied by Krastev 2002 and Kaminski 1997), and also through the course of enlargement of the European Union (Moroff and Schmidt-Pfister 2010).

In addition to the above mentioned factors, the differentiated levels of corruption between countries in itself may influence the survey infrastructure. A different effort is required to collect good quality data from countries where corruption is wide-spread and systemic. Respondents may be more willing to talk about corruption, switching the guilt from individuals to the system and feeling like victims (introducing comparability bias). On the other hand, given their everyday experience with corrupt institutions, interviewers and survey organizers may tend to bend the rules more frequently, given the often-limited funding and the often present time pressure. However, this assumption needs further investigation.

What is interesting about the large corruption topic coverage in public opinion survey projects is the ambiguity of a positive result. Do the problems of a country dictate topics for survey questionnaires? It can be assumed that a survey questionnaire, being a product of intellectuals who aim to analyze important matters of their own times, reflects social (or maybe generational) problems. Topics that appear in a questionnaire may be carefully and knowledgably selected by survey organizers, and take their place at the top of the list of important social issues to talk about, discuss and analyze. Independently from the underlying factors influencing uneven data on corruption in Europe, the problem with existent survey data deserves special attention, especially when generalizing results and using nested models in countries.

\section{ACKNOWLEDGEMENTS}

The research is partially supported by the Mobility grant of the Ministry of Science and Higher Education of Poland (1292/MOB/IV/2015/0). 


\section{NOTES}

1 Sometimes called the "bandwagon" or "snowball" effect, meaning that individual perception of corruption and tendency to behave in a corrupt way is influenced by the common perceptions of how others in a country behave. (Della Porta and Vannucci 2012, Malito 2014)

2 In 2016, GCB question module was implemented in Europe as part of LITS. Here and elsewhere in this text, the data for GCB/LITS 2016 are summed up to the total for LITS.

3 Additionally, (1) the data search tool of the ROPER Public Opinion Research Archive (https://ropercenter.cornell.edu/) may be useful - it archives polls and surveys mostly for the US, but also around the world; (2) the search tool developed by the World Bank, the Microdata Catalog, is available, although the amount of public opinion survey data within this collection is limited (3) The CESSDA Data Catalogue (under development) has promising aims of providing researchers with the possibilities of search within comprehensive metadata on existing surveys and variables within them.

4 Most of survey projects with data on corruption have separate samples for East and West Germany.

\section{REFERENCES}

Andersson, S., \& Heywood, P. M. (2009). The Politics of Perception: Use and Abuse of Transparency International's Approach to Measuring Corruption. Political Studies, 57(4), 746-767. https://doi.org/10.1111/j.1467-9248.2008.00758.x

Azfar, O., \& Murrell, P. (2009). Identifying Reticent Respondents: Assessing the Quality of Survey Data on Corruption and Values. Economic Development and Cultural Change, 57(2), 387-411. https://doi.org/10.1086/592840

Bertrand, M., \& Mullainathan, S. (2001). Do People Mean What They Say? Implications for Subjective Survey Data. American Economic Review, 91(2), 67-72. https://doi. org/10.1257/aer.91.2.67

Chabova, K. (2017). Measuring corruption in Europe: public opinion surveys and composite indices. Quality \& Quantity, 51(4), 1877-1900. https://doi.org/10.1007/ s11135-016-0372-8

Della Porta, D., \& Vannucci, A. (2011). The hidden order of corruption: an institutional approach. Union Road, Farnham, Surrey; Burlington, VT: Ashgate Pub.

Groves, R. M. (2004). Survey errors and survey costs. Hoboken, N.J: Wiley.

Heath, A. F., Richards, L., \& de Graaf, N. D. (2016). Explaining Corruption in the Developed World: The Potential of Sociological Approaches. Annual Review of Sociology, 42, 51-79. https://doi.org/10.1146/annurev-soc-081715-074213

Holmes, L. (2015). Corruption: A Very Short Introduction. Oxford University Press. https://doi.org/10.1093/actrade/9780199689699.001.0001

Kamiński, A. Z. (1997). Corruption Under the Post-Communist Transformation: The Case of Poland. Polish Sociological Review, (118), 91-117.

Kamiński, A. Z. \& Kamiński, B. (2004) Korupcja rząów: państwa pokomunistyczne wobec globalizacji. Instytut Studiów Politycznych PAN, Warszawa: Wydawnictwo TRIO.

Karalashvili, N., Kraay, A., \& Murrell, P. (2015). Doing the survey two-step: the effects of reticence on estimates of corruption in two-stage survey questions (World Bank Policy Research Working Paper No. 7276). https://doi.org/10.1596/1813-9450-7276 
Kolczyńska, M. (2014). Representation of Southeast European Countries in International Survey Projects: Assessing Data Quality. ASK: Research \& Methods, 23(1), 57-78.

Krastev, I. (2002). The corruption paradox: Why post-Communism is/looks more corrupt than Communism. Budapest, Hungary: Collegium Budapest.

Lynn P, Japec L and Lyberg L. (2006). What's so special about cross-national surveys?'

In: Harkness J (ed.) Conducting Cross-National and Cross-Cultural Surveys. Mannheim: GESIS, pp. 7-20.

Malito, D. (2014) Measuring Corruption Indicators and Indices (February 2014). Robert Schuman Centre for Advanced Studies Research Paper 2014/13. https://doi. org/10.2139/ssrn.2393335

Melgar, N., Rossi, M., \& Smith, T. W. (2010). The Perception of Corruption. International Journal of Public Opinion Research, 22(1), 120-131. https://doi.org/10.1093/ijpor/ edp058

Moroff, H., \& Schmidt-Pfister, D. (2010). Anti-corruption movements, mechanisms, and machines - an introduction. Global Crime, 11(2), 89-98. https://doi.org/10.1080/ 17440571003669118

Mungiu-Pippidi, A. (2016). The Quest for Good Governance: Learning from Virtuous Circles.Journal of Democracy, 27(1), 95-109. https://doi.org/10.1353/jod.2016.0000

Nieuwbeerta P, DeGeest, G., Siegers, J. (2003). Street-level corruption in industrialized and developing countries. European Societies, 5(2), 139-165. https://doi.org/ $10.1080 / 1461669032000072265$

Povitkina, M. \& Wysmułek, I. (2017) Quantitative methods in researching corruption: surveys, cross-national studies, and measurement issues. In A. Schwickerath, A. Varraich \& L.-L. Smith (eds.) How to Research Corruption. ICR_Forum_Amsterdam_Conference Procedings. Retrieved from http://nbn-resolving.de/urn:nbn:de:0168-ssoar-52393-1

Rose, R. and Peiffer, C. (2012) Paying bribes to get public services: A comparative guide to concepts and measures. (No. 494). University of Strathclyde Studies in Public Policy. Retrieved from https://papers.ssrn.com/sol3/papers.cfm?abstract_id=2180793

Rothstein, B. (2011). The quality of government: corruption, social trust, and inequality in international perspective. Chicago: University of Chicago Press. https:/doi. org/10.7208/chicago/9780226729589.001.0001

Słomczyński, K., \& Tomescu-Dubrow, I. (2006). Representation of Post-Communist European Countries in Cross-National Public Opinion Surveys. Problems of PostCommunism, 53(4), 42-52. https://doi.org/10.2753/PPC1075-8216530404

Słomczyński, Kazimierz M., Irina Tomescu-Dubrow, J. Craig Jenkins, with Marta Kołczyńska, Przemek Powałko, Ilona Wysmułek, Olena Oleksiyenko, Marcin W. Zieliński and Joshua K. Dubrow. (2016). Democratic Values and Protest Behavior. Harmonization of Data from International Survey Projects. Warsaw: IFiS Publishers. Słomczyński, K. M.; Jenkins, J. C.; Tomescu-Dubrow, I.; Kołczyńska, M.; Wysmułek, I.; Oleksiyenko, O.; Powałko, P.; Zieliński, M. W. (2017). SDR Master Box, Harvard Dataverse, V1. https://doi.org/10.7910/DVN/VWGF5Q

Smith, T. W. (2015). Resources for Conducting Cross-National Survey Research. Public Opinion Quarterly, 79(S1), 404-409. https://doi.org/10.1093/poq/nfv004

Wei, S.-J. (2000). How Taxing is Corruption on International Investors? Review of Economics and Statistics, 82(1), 1-11. https://doi.org/10.1162/003465300558533 
Wysmułek, I. (2016). Creating a 'Common File' of Source Variables for Ex-post Harmonization of International Surveys featuring Corruption Items. In TomescuDubrow, I. \& Dubrow, J. Harmonization: Newsletter on Survey Data Harmonization in the Social Sciences, 2(2), 19-24.

Wysmułek, I. (2017). Cross-national Surveys featuring Corruption Items in Europe (1989-2013), Harvard Dataverse, V1. https://doi.org/10.7910/DVN/WRVUTZ

\section{APPENDIX}

Appendix A1. Survey Data and Documentation Sources

\begin{tabular}{|c|c|c|}
\hline Abbr. & Survey Project & Data and Documentation Source \\
\hline ASES & Asia Europe Survey & ICPSR, www.icpsr.umich.edu \\
\hline $\mathrm{CB}$ & Caucasus Barometer & http://www.crrccenters.org \\
\hline CCEB & Candidate Countries Eurobarometer & GESIS https://dbk.gesis.org/dbksearch \\
\hline CDCEE & $\begin{array}{l}\text { Consolidation of Democracy in } \\
\text { Central and Eastern Europe }\end{array}$ & GESIS https://dbk.gesis.org/dbksearch \\
\hline CSES & $\begin{array}{l}\text { Comparative Study of Electoral } \\
\text { Systems }\end{array}$ & GESIS https://dbk.gesis.org/dbksearch \\
\hline EB & $\begin{array}{l}\text { Standard and Special Eurobarom- } \\
\text { eter }\end{array}$ & GESIS http://zacat.gesis.org/ \\
\hline EB_corr & $\begin{array}{l}\text { Eurobarometer Corruption } \\
\text { Themed }\end{array}$ & GESIS http://zacat.gesis.org/ \\
\hline EQLS & European Quality of Life Survey & UK Data Service http://discover.ukdataservice.ac.uk \\
\hline QoG & $\begin{array}{l}\text { European Quality of Government } \\
\text { Survey }\end{array}$ & https://qog.pol.gu.se \\
\hline ESS & European Social Survey & http://www.europeansocialsurvey.org \\
\hline EVS & European Values Study & GESIS https://dbk.gesis.org/dbksearch \\
\hline GCB & Global Corruption Barometer & Transparency International http://www.transparency.org \\
\hline ICVS & International Crime Victim Survey & http://wp.unil.ch/icvs/ \\
\hline ISJP & International Social Justice Project & GESIS https://dbk.gesis.org/dbksearch \\
\hline ISSP & $\begin{array}{l}\text { International Social Survey Pro- } \\
\text { gramme }\end{array}$ & GESIS https://dbk.gesis.org/dbksearch \\
\hline LITS & Life in Transition Survey & $\begin{array}{l}\text { http://www.ebrd.com/what-we-do/economic-research- } \\
\text { and-data/data/lits.html }\end{array}$ \\
\hline NBB & New Baltic Barometer & UK Data Service http://discover.ukdataservice.ac.uk \\
\hline NEB & New Europe Barometer & UK Data Service http://discover.ukdataservice.ac.uk \\
\hline PEW & Pew Global Attitudes Project & http://www.pewglobal.org/datasets/ \\
\hline VPCPCE & $\begin{array}{l}\text { Values and Political Change in } \\
\text { Postcommunist Europe }\end{array}$ & UK Data Service http://discover.ukdataservice.ac.uk \\
\hline WVS & World Values Survey & GESIS https://dbk.gesis.org/dbksearch \\
\hline
\end{tabular}


Appendix A2. Main Characteristics of Cross-National Surveys with Items on Corruption

\begin{tabular}{|c|c|c|c|c|c|}
\hline \multirow[b]{2}{*}{ Abbr. } & \multicolumn{4}{|c|}{ Surveys with items on corruption } & \multirow{2}{*}{$\begin{array}{l}\text { Number of } \\
\text { Corruption } \\
\text { items (total) }\end{array}$} \\
\hline & Survey name (abbreviation) & Timespan & Waves & $\begin{array}{c}\text { Europe } \\
\text { countries }^{*}\end{array}$ & \\
\hline EB_corr & Eurobarometer Corruption Themed & $2005-2017$ & 6 & 23 & 390 \\
\hline GCB & Global Corruption Barometer & $2003-2013$ & 8 & 31 & 349 \\
\hline LITS & Life in Transition Survey & $2006-2016$ & 3 & 27 & 126 \\
\hline ICVS & International Crime Victims Survey & $1992-2005$ & 4 & 22 & 108 \\
\hline ISSP & International Social Survey Programme & $1992-2017$ & 9 & 17 & 22 \\
\hline QoG & European Quality of Government Survey & $2010-2013$ & 2 & 21 & 20 \\
\hline EB & General Eurobarometer & $1997-2016$ & 13 & 27 & 18 \\
\hline CB & Caucasus Barometer & $2009-2017$ & 7 & 3 & 17 \\
\hline NBB & New Baltic Barometer & $1993-2004$ & 6 & 3 & 14 \\
\hline PEW & Pew Global Attitudes Project & $2002-2016$ & 6 & 8 & 11 \\
\hline CDCEE & $\begin{array}{l}\text { Consolidation of Democracy in Central and } \\
\text { Eastern Europe }\end{array}$ & $1990-2001$ & 2 & 13 & 11 \\
\hline NEB & New Europe Barometer & $1998-2004$ & 5 & 8 & 7 \\
\hline WVS & World Values Survey & $1989-2013$ & 5 & 16 & 7 \\
\hline CCEB & Candidate Countries Eurobarometer & 2003 & 2 & 12 & 5 \\
\hline ESS & European Social Survey & $2004-2010$ & 2 & 24 & 5 \\
\hline EQLS & European Quality of Life Survey & 2016 & 1 & 32 & 5 \\
\hline EVS & European Values Study & $1990-2008$ & 3 & 34 & 4 \\
\hline ISJP & International Social Justice Project & $1991-1996$ & 2 & 9 & 4 \\
\hline ASES & Asia Europe Survey & 2000 & 1 & 9 & 3 \\
\hline VPCPCE & $\begin{array}{l}\text { Values and Political Change in } \\
\text { Postcommunist Europe }\end{array}$ & 1993 & 1 & 5 & 2 \\
\hline CSES & Comparative Study of Electoral Systems & 2001 & 1 & 23 & 1 \\
\hline TOTAL: & & $1989-2017$ & 89 & $1587^{* *}$ & 1129 \\
\hline
\end{tabular}

${ }^{*}$ Average number of European countries per survey project wave

** Total number of country/survey/year units 